\title{
What's Distinctive about Growth-Oriented Entrepreneurship in Developing Countries?
}

Article in SSRN Electronic Journal · March 2005

DOI: $10.2139 / \mathrm{ssrn} .742605$

CITATIONS

46

3 authors, including:

\section{David C. Lingelbach}

University of Baltimore

20 PUBLICATIONS 96 CITATIONS

SEE PROFILE
READS

152
Lynda De La Vina

University of Texas at San Antonio

12 PUBLICATIONS 171 CITATIONS

SEE PROFILE

All content following this page was uploaded by Lynda De La Vina on 19 June 2017. 


\title{
WHAT'S DISTINCTIVE ABOUT GROWTH-ORIENTED ENTREPRENEURSHIP IN DEVELOPING COUNTRIES?
}

\author{
David Lingelbach \\ University of Texas at San Antonio and The Johns Hopkins University \\ David.Lingelbach@utsa.edu \\ Lynda de la Viña \\ University of Texas at San Antonio \\ Lynda.DeLaVina@utsa.edu \\ Paul Asel \\ International Finance Corporation and George Mason University \\ pasel@ifc.org
}

\begin{abstract}
Entrepreneurship in emerging markets is distinctive from that practiced in more developed countries. Better understanding these distinctions is critical to private sector development in developing countries. Of particular interest are new and growth-oriented enterprises, which have a greater capacity to create sustainable economic growth than microenterprises or longestablished SMEs with limited growth prospects. The distinctions between growth-oriented entrepreneurs in developing and developed markets are rooted in the inefficiency of markets in many developing countries, but the response of entrepreneurs to these inefficiencies is often surprising and counterintuitive. These findings call into question the policy approaches to entrepreneurship development often advocated.

While noting the possible lack of correlation between business environment and levels of growth-oriented entrepreneurship, we focus on three key distinctions: opportunity, financial resources, and apprenticeship and human resources. These distinctions suggest a rich research and policy reform agenda.
\end{abstract}

\section{INTRODUCTION}

The wealth and poverty of developing countries has been linked in modern times to the entrepreneurial nature of their economies. Where it has existed in plenty, entrepreneurship has played an important role in economic growth, innovation, and competitiveness, and it may also play a role over time in poverty alleviation (Landes 1998). Yet, entrepreneurship in developing countries is arguably the least studied significant economic and social phenomenon in the world today. Over 400 million individuals in developing countries are owners or managers of new firms (Reynolds et al. 2004). Of these, over 200 million are found in China and India alone ${ }^{1}$, compared with just 18 million entrepreneurs in the United States. Yet, in one of the best general books on the state of research on entrepreneurship, China is mentioned on two pages and India is not mentioned at all (Bhidé 2000).

Specialist literature has focused on describing the attributes of entrepreneurship in developing countries, rather than providing a framework in which entrepreneurs and policy makers alike can more rationally plan and execute innovative business models. Existing models 
of entrepreneurship, such as Bhidé's uncertainty/investment/profit diagram, are based largely on research conducted in the United States and other developed countries and do not adequately describe how entrepreneurship is carried out in developing countries.

Until recently we have understood little about entrepreneurship in developing countries, particularly the characteristics of new and growth-oriented firms. Scholars and practitioners alike have implicitly assumed that entrepreneurship was largely the same the world over-driven by the same impulses that played on homo economicus everywhere. Research in behavioral economics and finance has advanced our understanding about the limits of rationality in describing economic behavior such as entrepreneurship. In particular, the cognitive bias of overoptimism has helped us to understand why entrepreneurs start businesses in the face of odds of firm survival (often less than 50\%) that would argue otherwise. In relation to developing countries, the most rewarding future research effort in this area may be to analyze the "differences in ambiguity aversion, self-control, susceptibility to framing and so (that) play a crucial role in the formation and evolution of businesses" (Bhidé 2000). How these differences may vary across countries, and the underlying drivers of these differences, may help us to gain a better understanding of why some countries have more successful entrepreneurs than others.

More recent empirical research-most notably based on the World Business Environment Survey (WBES) and the Global Entrepreneurship Monitor (GEM) project-have helped us to better understand the diversity, if not the dynamics, of new firm formation in developing countries. While methodological weaknesses may limit the robustness of the GEM data, they offer the first broad cross-country comparisons of entrepreneurship and, in particular, allow comparisons of the levels and possible drivers of opportunity-based ${ }^{2}$ entrepreneurship. Recent research (Romer 1990, Beck et al. 2004) has reminded us that new firms are more likely to grow. Growth-oriented firms are more likely to create new employment opportunities than stagnant ones.

We suggest in this paper that one of the outcomes of this recent research is the notion that entrepreneurship in developing countries is distinctive from that practiced in developed countries, and that understanding these distinctions is critical to private sector development in developing countries. We seek to illustrate what some of these distinctions might be, based both on recent research and our own experience as entrepreneurs, investors, and advisors on entrepreneurship to development finance institutions throughout the world. We conclude the paper by highlighting what some of the research and policy implications of these distinctions might be.

\section{LITERATURE REVIEW}

Entrepreneurship is not a well-developed component of modern economic theory. Many neoclassical economists find it difficult to reconcile the requirements of rational decision-making with the functions ascribed to entrepreneurship-coordination, arbitrage, innovation, and uncertainty bearing (Barreto 1989). Entrepreneurs have been described variously as bearers of risk (Cantillon 1755 and Knight 1921), agents that bring together the factors of production (Say 1803), or organizers of innovation (Schumpeter 1942). However, none of these thinkers distinguished between entrepreneurs operating in different business environments or considered differences between entrepreneurship in wealthy and poor countries at various stages in economic history. 
Academic interest in entrepreneurs in developing countries began in the wake of decolonization, with interest until recently concentrating mainly on small-scale industrialization (for example, Schmitz 1982) and microenterprises (for example, Robinson 2001-2). Four types of entrepreneurial firms have been identified in developing countries: newly established, established by not growing, established but growing slowly, and graduates to a larger size (Liedholm and Mead 1999). With respect to the study of the subset of new and growth-oriented firms in developing countries, an important step forward has been the rich output of the GEM project, which, despite methodological shortcomings ${ }^{3}$, has begun to give us a better sense of entrepreneurship's diversity across the world. Of particular interest to the subject of this paper has been the project's recent work on identifying the factors associated with variations in national entrepreneurial activity. These data, which are disaggregated into poor and wealthy countries and which distinguish between necessity and opportunity entrepreneurs, suggest several important, but counterintuitive findings:

- Freer, more competitive, poor countries are not correlated in a statistically significant way with higher levels of opportunity entrepreneurs.

- Recent economic growth in a poor country is not correlated in a statistically significant way with higher levels of opportunity entrepreneurship, and;

- Protection of property rights and levels of corruption don't seem to matter either ${ }^{4}$.

While these results must be treated with caution and subjected to peer review, they may call into question some of the recent efforts of development finance institutions to promote entrepreneurship through improvement of the general business environment, which are in turn based on the findings of institutional economics.

\section{WHAT MAKES ENTREPRENEURS IN DEVELOPING COUNTRIES DIFFERENT?}

Some distinctive attributes of entrepreneurship in developing countries appear to improve the probability of success for growth-oriented firms, while others appear to hold back these firms.

\section{Opportunity}

Opportunities for entrepreneurs in developing countries are broader in scope than in developed markets, allowing firms to pursue a portfolio approach to strategy that can efficiently manage the higher levels of business and market risk. Entrepreneurs in developing countries face a different set of circumstances than their counterparts in developed economies. These differences are rooted in the underlying economies in which they operate. Emerging markets lack a stable of mature markets and the consistency that such markets offer. Consequently, the opportunity for entrepreneurship in emerging markets is pervasive. While Western entrepreneurs operate at the fringes of the economy, emerging market entrepreneurs operate closer to the core the needs and opportunities are more widespread.

While the competitive threat to these entrepreneurs from well-established incumbents is reduced, the risks posed by economic, political and regulatory uncertainty is heightened-often outweighing direct competitive threats. The rational, though counter intuitive, response (especially for those trained in Western business strategy) is for entrepreneurs in developing countries to spread resources across several separate but related businesses in order to mitigate 
systematic risk. In effect, the entrepreneur operating in segmented markets (a feature of many developing countries) often plays a surrogate role as a financial investor who manages risk through portfolio diversification. He manages portfolio risk by operating several diverse businesses in lieu of investors who might otherwise do the same. Lacking alternative sources of financing, the successful entrepreneur may use internally generated cash flow from one business to fund his other businesses. The keiretsu system in Japan and chaebols in Korea are examples of highly developed conglomerates with interlocking ownerships and business partnerships that developed in this manner. In addition to risk mitigation and a source of funding, interlocking businesses provide a source of informal information flow, access to a broader pool of skills and resources, and, when well implemented, a brand name that can be leveraged across all businesses.

If interlocking business conglomerates are common in emerging markets, how do they start? Inadequate access to capital and fragmented retail and distribution often require entrepreneurs to begin businesses downstream with direct access to the end customer. Starting downstream businesses reduces initial capital requirements as working capital is much reduced and permits access to customers and information flow that is frequently lacking. Access to such information is often overlooked as a key success factor. Lack of access to the end customer is a primary reason for the failure of South American businesses to move beyond commodity markets into higher value added activities (Fairbanks and Lindsay 1997). Having achieved success in retail and distribution, successful entrepreneurs often leverage the domain experience, information flow, and cash flow generated to vertically integrate and move into upstream businesses.

\section{Financial Resources}

While entrepreneurial opportunities are broader and resultant strategies are naturally selfhedging in developing countries, limited personal and family savings and an absence of financial innovation severely limits the growth prospects of promising startups in developing countries. The nature of entrepreneurial opportunities in developing countries plays a critical role in the market for entrepreneurial finance in these countries. To a greater extent than in developed countries, nascent entrepreneurs must answer the following fundamental financial questions: if the odds of a new enterprise surviving its first five years are less than $50 \%$, is it rational for an entrepreneur to commit financial resources (her own or others) to a new firm? If not, how can we understand the persistent tendency of entrepreneurs to start new businesses? And how can we make sense of financing businesses whose odds of success are often less than that of a coin toss?

Reflecting the unpromising odds of entrepreneurial success, internal finance comprises the majority of financing for small and medium enterprises in most developing countries.

Entrepreneurs in emerging markets rely very heavily on informal sources of finance to start their businesses; these sources provided between $87 \%$ and $100 \%$ of the outside capital raised by entrepreneurs (Bygrave 2003). Other sources of financing typically targeted by development finance institutions interested in improving access to finance in the emerging markets-bank lending and venture capital—play a very limited role at present in financing entrepreneurs, at least in the startup stage.

Very little is understood about the mechanisms by which potential entrepreneurs in developing countries gather the capital necessary to start a business. How do entrepreneurs save funds from their own sources of income in order to start a business? Recent evidence suggests 
that startup capital requirements could be quite modest in developing countries (for example, Bhidé 2004 and Johnston et al. 2004). There are two issues here: sources of income, and appropriate depositories for savings until the new business is started. Sources of income can include retained earnings from a previous business, often in the retail or distribution sector. In countries where well-paid government positions are still available (such as the Middle East), some potential entrepreneurs are able to save start up capital from their salaries.

Research on the determinants of private savings in developing countries suggest that countries that have experienced economic instability are more likely to have higher rates of private saving, maintained as an insurance mechanism (Loayza, Schmidt-Hebbel, and Servén 2000). Crisis represents opportunity, at least as far as forming the pools of private capital necessary for startup finance is concerned. Moreover, while successful entrepreneurship is correlated with urbanization, urbanization also results in an increase in individual consumption and a concomitant decrease in private savings. Thus, successful entrepreneurs are likely to find ways to access the greater pools of private saving in the countryside in order to start their businesses. This highlights the possible importance of well-developed family networks that span both urban and rural areas. How such private rural savings are intermediated into urban entrepreneurship is not at present well understood and almost certainly will vary by country.

In theory, microenterprises could also play a role in creating a pool of savings from which a larger, more sophisticated enterprise might be launched. However, a shortage of attractive savings mechanisms (including negative real interest rates on bank deposits) in the formal and informal financial sectors and the difficulties associated with investing in land or real estate as a savings vehicle (including land tenure issues) have severely limited savings. Other forms of de facto savings, such as inventory accumulation, are also limited by the absence of secure premises (Grosh and Somolekae 1996). These are some of the many reasons why microenterprises have not generally served as launching pads for growth-oriented entrepreneurship in developing countries.

Finally, an important, but overlooked and undocumented, development is the increasingly consumerist nature of developing country economies, which has caused personal savings rates to fall and personal consumer-related indebtedness to grow. Anecdotal evidence from regions such as the Middle East and North Africa suggest that inappropriate levels of personal indebtedness may severely constrain an entrepreneur's willingness and capability to start a new firm.

Once established, new firms use a wide variety of unconventional techniques and strategies to obtain finance. Given the underdeveloped nature of financial markets in many developing countries, bootstrap financing may have become the predominant form of early stage financing in these countries. For example, small-scale Chinese entrepreneurs have designed a wide variety of techniques and institutions to provide informal finance (Tsai 2002). Why have outside, formal sources of financing, particularly forms of risk capital finance required by growth-oriented entrepreneurs in emerging markets, failed to materialize in substantial quantities? One major reason is that the macroeconomic conditions in many emerging markets militate against the high IRRs that investors require in order to compensate them for their risk (Leeds and Sunderland 2003). As a result, while there are no industry-wide statistics on private equity investing in emerging markets, it is estimated that realized IRRs are roughly breakeven for the first generation of such funds (those started in the early 1990s). It goes without saying that such returns are insufficient to attract large amounts of new investment into the next generation of risk capital vehicles. 
Risk capital finance is particularly important for growth-oriented entrepreneurs in the developing world, because it aligns the incentives of entrepreneurs and outside investors. Each is properly motivated to maximize economic value of the enterprise, rather than playing zero-sum games designed to benefit at the expense of the other. Such zero-sum games are typical of commercial bank lending to entrepreneurs in developing countries. In addition, properly designed and staffed fund management organizations can add substantial post-investment value to the growth-oriented entrepreneurial enterprise. Lenders do not have incentives to provide such post-investment assistance. Post-investment value creation is often a key to the development of growth-oriented entrepreneurial enterprises.

While risk capital finance has been an important component of the entrepreneurial process in a number of developed countries, it has not realized its promise in the developing world. The American model of venture capital has had limited applicability in these markets, but has often been the first approach taken by fund managers focused on developing countries. Venture capital funds are able to work with only small numbers of companies, limiting their development impact. Venture capital and private equity funds have been unable to exit many of their investments, due to the illiquidity of local stock markets in developing countries. Successful venture capitalists possess relatively rare skills that can generally be acquired only through experience, rather than through education and training, thus limiting the number of risk capital organizations that can be organized. Current forms of risk capital finance require the setup of new institutions (usually both a fund and a fund management company) before commencement of investment operations, thus slowing the investment process and causing funds to invest too late in the investment cycle in many cases.

How might some of these hurdles be overcome? Surprisingly, despite the revolution in finance that has swept through developed capital markets over the past fifty years, little financial innovation has made its way to entrepreneurial firms in developing countries. As one example, income-linked loans (loans, the repayment of which is tied to a borrower's future income) were first introduced to finance higher education in the United States (Shiller 2003), but could be applied to other classes of borrowers, including entrepreneurial firms in developing countries. Lenders (commercial banks, non-bank financial institutions, fund managers, and others) could offer long-term (10 years or more) loans to entrepreneurial borrowers. The repayment terms of these loans would be tied to both the firm's future income and some index of aggregate incomes. This index of aggregate incomes might include borrowers from the same sector throughout a region (for example, all garment manufacturers in Indonesia), corporate borrowers from any sector but in the same geographic region (for example, all corporate borrowers in Brazil), or a combination of the two.

\section{Apprenticeship and Human Resources}

Technical, industry-specific training is an important component in the creation of globally competitive firms (Porter 1998 and Kantis and Ishida 2002). These firms often form into geographically focused industrial clusters (Porter 1998). Indeed, we have found this to be a powerful model that can be extended to the emergence of globally competitive industries in developing countries. The software cluster in India, the animation outsourcing cluster in the Philippines, and the wireless market in China each conform to varying degrees with the specifications of clustering. 
However, the clustering model is of limited value for the vast majority of entrepreneurial opportunities and those involved with public policy in markets where essential preconditions do not yet exist and may not be construed. It is not clear that clustering is a precondition for the creation of globally competitive firms in developing countries-Jollibee and Cemex are examples to the contrary. In addition, what is to be done about industries in which the market size is national and sub-national and business conditions are essentially homogenous? How does one operate in emerging markets without the normal avenues of preparation and mentorship? What does one do when in mal-developed or corrupt economies where leading companies do not necessarily serve as the best guides for new businesses? How do businesses achieve scale in the absence of certain skill sets domestically such as financial management?

Entrepreneurship is a lonely profession rendered more difficult without the benefit of mentorship and apprenticeship. Leading hotspots of innovation such as Silicon Valley have a broad pool of well-trained talent, a culture that encourages innovation and new businesses, and marquee companies that serve as informal finishing schools for entrepreneurs. Even in the absence of these ideal situations, apprenticeship and entrepreneurship may be developed in tandem. At the most rudimentary level, micro lending organizations have found that repayment and business success rates increase markedly with even the most basic business training and local support groups of like-minded entrepreneurs. Unfortunately, few of these enterprises scale to regionally competitive levels, let alone national or global levels.

At a higher level, multinationals have played a leading role as training grounds for prospective entrepreneurs. Given that foreign direct investment by multinationals is often directly related to the general business environment, and that apprenticeship in these firms can be an important road to entrepreneurship, we shall need to reconcile these observations with the lack of correlation of levels of entrepreneurship with the general business environment. In those markets where entrepreneurship has flourished, successful local businessmen may serve as mentors and outside advisors. As a business expands, corporate governance supersedes mentorship as requisite guidance and oversight; a mix of savvy local businessmen and industry experts, even if attracted from abroad, play an important role during this expansion stage.

Emerging markets require revolutionary change but have few people with the requisite skills and experience to effect such change. High potential businesses in developed economies assemble executive teams with common experiences but diverse, complementary skills. Potential stakeholders look for thoughtfully selected, complete teams that include experienced executives in sales, marketing, finance and operations. In emerging markets, these skills are equally valid but often in short supply. As a result, entrepreneurs look for other characteristics that are pertinent to the local market environment, including the ability to see through the fog of politics and economics in crisis-prone developing countries. Trust is even more highly regarded in these situations than in developed markets where arms-length transactions are well

established. Family owned and operated businesses are even more common in emerging markets than in Western economies.

\section{POLICY AND RESEARCH IMPLICATIONS}

Entrepreneurship in developing countries is the most understudied important global economic phenomenon today. Our paper has highlighted some of the possible distinctive features of this phenomenon, but it has raised more questions than it has answered. Amongst the most promising avenues of research, with important policy implications, are the following: 
- A refocus on new and growth-oriented firms - most of the specialist research in this field concentrates on microenterprises and low-growth lifestyle businesses, yet these firms do not contribute in a meaningful way to the sustainable economic growth needed to reduce poverty in developing countries. Recent research strongly suggests that new and growth-oriented firms are more likely to contribute to economic growth and provide important new sources of higher quality employment. More research should be conducted on the unique attributes of new and growth-oriented firms.

- Dynamics of firm creation and destruction - while we are beginning to develop snapshots of entrepreneurial sectors in certain developing countries, we are not yet able to form a clear picture of the dynamics of these sectors. How many firms are created, and how many are dying? What are the drivers of firm creation and destruction in developing countries? How do these dynamics compare across developing countries?

- The personal finance linkage to new firm formation - we understand very little about the personal finances of current and nascent entrepreneurs in developing countries. Personal savings rates and intra-familial financial linkages seem to be critical areas for empirical research, given that access to finance continues to be cited as an important barrier to new firm formation.

- Validating GEM results about apparent lack of correlation between general business and macroeconomic conditions and opportunity entrepreneurship - the apparent lack of correlation between the general business environment and the level of entrepreneurial activity in countries categorized by GEM as "poor" needs to be validated and better understood. The data need to be reanalyzed, utilizing World Bank definitions of low and middle income countries. Moreover, the data need to be analyzed for possible correlations between business environment and successful entrepreneurship, not just general levels of entrepreneurial activity.

- Models of success - we lack rigorous studies focused on successful entrepreneurs in developing countries. At present, such work is limited to a handful of case studies. Are there common features of successful entrepreneurship in developing countries, and to what extent are they different from features of successful entrepreneurship in places such as the United States?

- Financial innovation — how do we design markets for entrepreneurial finance in developing countries? How do we extend financial innovations such as hedging and insurance to entrepreneurs in developing countries, in ways that allow them to more effectively manage risk?

- Applying behavioral economics and finance to entrepreneurship in developing countrieshow do the myriad cognitive biases identified by behavioral economics and finance vary for entrepreneurs in developing countries? What are the implications for entrepreneurs and policy makers? 


\section{REFERENCES}

Barreto, Humberto (1989), The Entrepreneur in Microeconomic Theory, London: Routledge.

Beck, Thorsten, Asli Demirgüç-Kunt, and Ross Levine (2004), "SMEs, Growth, and Poverty: Cross-Country Evidence," paper presented at the Conference on Small and Medium Enterprises, sponsored by the World Bank’s Development Research Group, October.

Bhidé, Amar V. (2004), “What Holds Back Bangalore Businesses?,” unpublished working paper, December, accessed at www.bhide.net.

Bhidé, Amar V. (2000), The Origin and Evolution of New Businesses, New York: Oxford University.

Bygrave, William D. (2003), "Financing Entrepreneurs and Their Businesses," working paper presented at the First Annual Global Entrepreneurship Symposium, United Nations, April.

Cantillon, Richard (1755), “Essai Sur la Nature du Commerce en Général,” London, translated by Higgs, accessed at http://cepa.newschool.edu/het/profiles/cantillon.htm.

De Soto, Hernando (2003), The Mystery of Capital, New York: Basic Books.

Fairbanks, Michael and Stace Lindsay (1997), Plowing The Sea: Nurturing The Hidden Sources of Growth in the Developing World, Cambridge: Harvard Business School.

Grosh, Barbara and Gloria Somolekae (1996), "Mighty Oaks from Little Acorns: Can Microenterprise Serve as the Seedbed of Industrialization,” World Development, Volume 24, Number 12.

Johnston, Don E., John Magill, Michael McPherson, and Zan Northrip (2004), "Finance for Small and Medium Enterprise in Indonesia-Final Report," unpublished, prepared for Japanese Bank for International Cooperation, August.

Kantis, Hugo and Masahiko Ishida (2002), Entrepreneurship in Emerging Economies: The Creation and Development of New Firms in Latin America and East Asia, Washington: InterAmerican Development Bank, accessed at www.iadb.org.

Knight, Frank (1921), Risk, Uncertainty, and Profit, Boston: Houghton Mifflin.

Landes, David (1998), The Wealth and Poverty of Nations, New York: W.W. Norton.

Leeds, Roger S. (2003), Financing Small Enterprises In Developing Countries: Learning From Experience, White Plains: Transnational.

Leeds, Roger S. and Julie Sunderland (2003), "Private Equity Investing In Emerging Markets," Journal of Applied Corporate Finance, Volume 15, Issue 4, Fall.

Liedholm, Carl and Donald C. Mead (1999), Small Enterprises and Economic Development, London: Routledge. 
Loayza, Norman, Klaus Schmidt-Hebbel, and Luis Servén (2000), "What Drives Private Saving Across The World?," The Review of Economics and Statistics, Volume 82, Number 2, May.

Porter, Michael (1998), The Competitive Advantage of Nations, New York: Free Press.

Reynolds, Paul D., William D. Bygrave, and Erkko Autio (2004), Global Entrepreneurship Monitor: 2003 Executive Report, accessed at www.gemconsortium.org.

Robinson, Marguerite (2001-2), The Microfinance Revolution, 2 volumes, Washington: World Bank.

Romer, Paul M. (1990), “Endogenous Technological Change,” Journal of Political Economy, Volume 98, Issue 5.

Say, Jean Baptiste (1803), A Treatise on Political Economy, Philadelphia: Lippincott Grambo.

Schmitz, Hubert (1992), "Growth Constraints on Small-scale Manufacturing in Developing Countries: A Critical Review,” World Development, Volume 10, No. 6, pp. 429-450.

Schumpeter, Joseph (1942), Capitalism, Socialism, and Democracy, London: George Allen \& Unwin.

Shiller, Robert (2004), The New Financial Order, Princeton: Princeton University.

Tsai, Kellee S. (2002), Back-Alley Banking: Private Entrepreneurs in China, Ithaca: Cornell.

\section{NOTES}

${ }^{1}$ Indeed, as suggested by Michael Klein at a recent World Bank conference, these countries may be the best laboratories in which to study the new ways in which entrepreneurship develops and evolves.

${ }^{2}$ Reynolds et al. (2004) distinguish between necessity and opportunity-based forms of entrepreneurship. Necessity entrepreneurs are forced into new firm creation by unemployment or other economic shocks, while opportunitybased entrepreneurs make an affirmative choice to start a new business, based on the identification of a specific business opportunity.

${ }^{3}$ These shortcomings include the definition of "poor" countries, and the utilization of telephone sampling techniques.

${ }^{4}$ These conclusions are based on Tables 17 and 18 in Reynolds et al. (2004). 